\title{
ACCELERATING DIGITALISATION IN BUSINESS PRACTICES FOR SOCIAL VALUE CREATION: A PERSPECTIVE FROM MALAYSIA Nur Syuhada Jasni ${ }^{1 *}$, Haslinda Yusoff ${ }^{2}$ \\ ${ }^{1 * 2}$ Faculty of Accountancy, Universiti Teknologi MARA Selangor, Malaysia. Email: ${ }^{1 *}$ nursy168@uitm.edu.my, ${ }^{2}$ hasli229@uitm.edu.my
}

Article History: Received on $25^{\text {th }}$ February 2020, Revised on $18^{\text {th }}$ August 2020, Published on $29^{\text {th }}$ September 2020

\begin{abstract}
Purpose: The purpose of this study is to investigate the business practices in both; accelerating digitalisation and addressing social issues among Malaysian companies.

Methodology: This study uses a sample consisting of four top telecommunication companies listed in the Bursa Malaysia. This study provides relevant literature on the social value creation concept from the corporate perspective. Besides, content analysis is used to extract relevant information from the particular sustainability report of the companies.

Results: Results indicate that three out of four companies in the sample are very proactive in embracing the social value creation concept that aligned with national objectives and Sustainability Development Goals (SDG). Although, similarly, all companies addressed providing rural and urban poor communities' digitalisation assistance as their social contributions.

Implications: These results reveal input on the integration of accelerating digitalisation and addressing social issues, that focusing on social value creation. Management should understand that the financial implications has become an important component of social projects in line. Hence should establish effective strategic business strategy towards Integrated Reporting (IR) 4.0 that in reality has significant impact on the society and country.
\end{abstract}

Keywords: Digitalisation, Social Value Creation, Telecommunication, Business Strategy, Sustainability Development Goals.

\section{INTRODUCTION}

Almost all industries in the world are feeling the heat of the digital revolution. The revolution started from digitisation; where the manual and analogue change to automated and numerical processes. The digitisation affecting the telecommunication industry began in the year 1990s (Negroponte, 1995). However, rapid changes were seen in telecommunication networking from 2010 onwards when the internet been introduced and improved (Passig \& Scholz, 2015), resulting in many businesses shifting to use digital technologies in the business operation (Ernst \& Young, 2017a). The uses of digital technologies are also known as digitalisation, which assists in unlimited boundaries and opportunities for business growth. Today, the digitalisation has profound the customers' lifestyle (Keegan, 2012). Undoubtedly, eased the process of many individuals' daily routine in several ways including work culture to communication style from anywhere to everywhere. Hence provides flexible atmosphere to manage working and personal matters simultaneously.

Another wave of the digitalisation made possible by telecommunication companies are the Internet of Things (IoT) and cybersecurity (Ernst \& Young, 2016). Currently, IoT is unlocking the integration between human and computer technologies to exchange information for value creation. However, malicious users could manipulate digital technologies for their benefits. Hence, cybersecurity is another priority for digital users. Many IoT digital innovators save their data in cloud storage, hence data collected from the customers are reliable (as detailed as birthdate to any preferences) and known as oil of the digital age (Brusteinfeb, 2012). Larson (2017) claimed that big data from the data collected would enhance data analytics of the market research team. The algorithms could transmit detailed information about customers' characteristics and can find suitable solutions if any problems occurred.

The digitalisation also affected businesses strategies of many companies. For instance, an industry that experienced a significant impact on the digital technology vivid revolution of was music industry, which the physical cassette and CD was unfavourable and consumer favour digital music instead (Berman, 2012). The digital music is more attractive compared to traditional medium because consumer can be easily purchased by download it from iTunes or other sources in mp3 format. The revolution with the internet has changed the corporate landscape today, which a peak calling for businesses to redesign their business models to meet the digitalisation trend (Fuentes, Bäckström, \& Svingstedt, 2017). Berman (2012) suggested companies take action in competitive differentiation strategies that focus on the integration of two master plans: reassessing customers' values and adopting digital technologies for operations and collaboration with customers. Hence there is also no exceptions for service provider companies like telecommunication companies, they also need to redesign their business model and offer value-added services to win market share.

Government support plays a significant role to provide a good ecosystem in digitalisation development. Malaysia is ranked sixth in the top 10 most tech-savvy countries in the world (World Economic Forum, 2017), indicating that this 
country is network-ready. The economy of Malaysia has gone through a few transitions; the key changes of digitalisation started in August 1996, when Multimedia Super Corridor (MSC) launched in the intelligent city, Cyberjaya. The knowledge-driven domain (Yigitcanlar \& Sarimin, 2015) has grown faster since then as a global ICT hub in the region. In 2014, the Malaysian Global Innovation and Creativity Centre (MaGIC) was established to nurture Malaysian entrepreneurs' success and promote Malaysia as a hub of small-medium enterprise and internet start-ups. Accordingly, for digitalisation development regulation, Malaysia has developed a few guidelines: National Internet of Thing (IoT) Strategic Map in 2015 (Figure 1) and National e-Commerce Strategic Roadmap in 2016 (Figure 2). In 2015, an ecommerce consultant, ATKearney has identified the main obstacles of SME and consumers in Malaysia to be poor bandwidth and limited network coverage. Therefore, the allocation that amounted to MYR 1 billion in Budget 2017 should be an advantage to boost the coverage and quality of broadband and double the broadband speed at half the price in two years. Also, the target for a digital economy nation becomes clearer with the Digital Free Trade Zone (DFTZ) set up in March 2017, as a regional e-fulfilment centre and becoming the regional hub for SMEs, marketplaces, and brands. DFTZ has the potential to double the growth rate of Malaysian small and medium enterprises' (SMEs). Although the Malaysian market may be small in population compared to other countries in this region, Malaysia is standing strong and confident (Mottain, 2017), because digitalisation is borderless and opens the opportunity to penetrate the global market.

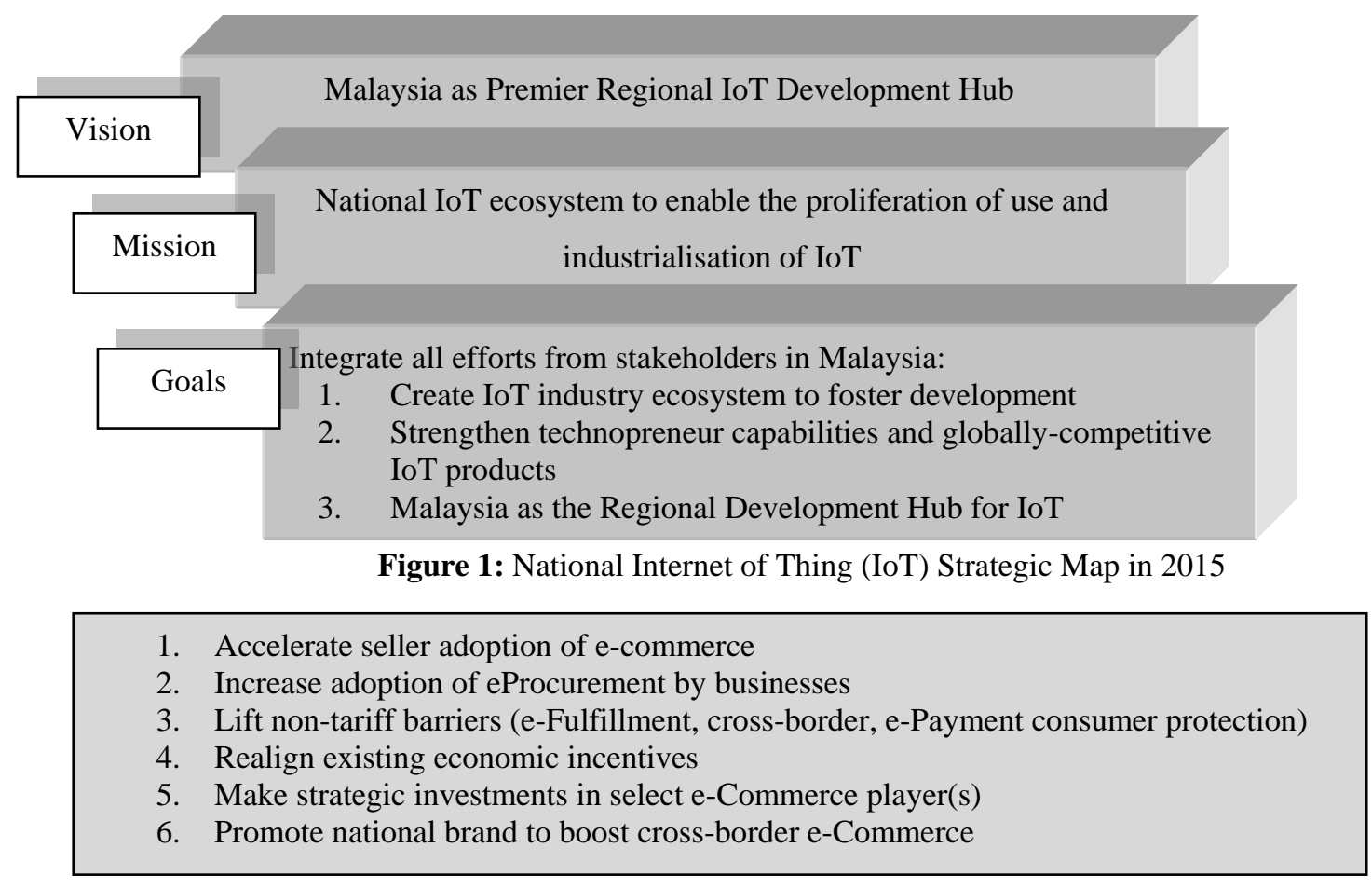

Figure 2: National e-Commerce Strategic Roadmap in 2016

The business strategies towards social value creation also align with United Nations (UN) announcement of 17 global Sustainable Development Goals (SDG) in 2015, which covered wide range goals to transform our world, purposely to end poverty, overcome inequality and injustice, and deal with climate change by 2030. A holistic approach of SDG requires a new way of thinking as the goals are complex and interconnected that involved stakeholders. SDG are proactively addressed and solve the challenges and create opportunities in consideration of four key themes: growth, risk, capital and purpose (Ernst \& Young, 2017b). A year after, a post-study made by Accenture \& United Nations Global Compact (2016) involved 1,000 CEOs from more than 100 countries showed that 87\% consider that SDG provide an essential opportunity to rethink approaches to sustainable value creation. Besides, nearly half, $49 \%$, believe that business will be the single most important factor in delivering the SDGs and $89 \%$ agree that commitment to sustainability is translating into real impact in their industry. SDGs can play essential role in ensuring business operations align with sustainability development.

The research objectives of this study are two folds; 1) to explore business practices taken by telecommunication companies in accelerating digitalisation and addressing social issues, and; 2 ) to investigate social value creation resulting from accelerating digitalisation initiatives. Meanwhile, the contributions of the study are attempted to fill in the gap by analysing the business practices related to the social projects executed by those companies and the value created for society. The particular social issues in the digital ecosystem discussed in this study consist of the involvement of young talents and women, digital risks, rural barriers, and IoT (smart city). In the Malaysia context, however, little is known about how proactive telecommunication companies as the service providers embraced digitalisation in reacting to social issues as in national and international agendas.

The outline of the paper is organised as follows: the next section discusses the digital development in the Malaysia 
context, literature review, research method, results and discussion, and finally, conclusions and future research agenda.

\section{LITERATURE REVIEW}

Social Issues: In discussions of social cases, one controversial issue related to corporate actions that have been received considerable critical attention as the motive was exploitive rather than contributing to the wealth and health of developing countries was Nike's case, their factories in developing countries deal with modern slavery issues in the 1990s, as they were accused providing poor employment such as e.g. slave wages, forced overtime, child labor (see: Gray, Adams, \& Owen, 2014; Paetzold, 2011). Other social issues involving Multinational Companies (MNCs) are; Nestle has been accused of unethical behaviour in misleading marketing promoting milk formulas against breastfeeding in Bangladesh in the 1970s and people still reflected the case until today, meanwhile current case, in 2018, Coca Cola has been allegations of groundwater depletion and pollution in India. Hence, MNCs received backlashed and boycott by the public as the social and human capital of the developing countries have been exhausted (Lee \& Kim, 2014) by their irresponsible corporate behaviour.

Although the discussion of corporate actions came across in the middle of debated against capitalism that focuses on solely profit-oriented. The stand for "profit versus purpose" has been started in the 1970s, as management theorist, Peter Drucker explained in his book "Management: Tasks, Responsibilities, and Practices" pointed out that the main purpose of the corporation is to serve the market and the customer (Drucker, 1973). Similarly, Paul Polman, CEO of Unilever, asserts that business is here to serve society and should focus on sustainable growth (Polman, 2014). Profit is just an indicator of business performance for business advantages that could not solve societal demands. Therefore, business goals should be beyond maximizing shareholder and accountable to the wider interests of their stakeholders. There is an increasing trend towards multidimensional reporting $(\mathrm{Kolk}, 2010)$ and the move towards integrated reporting to provide a holistic picture of value creation over time) (Integrated Reporting Committee (IRC) of South Africa, 2011; KPMG, 2011).

Furthermore, from a theoretical point of view, this study is an attempt to consider stakeholder theory which provides the most solid foundation for this study. Stakeholder theory arising more from political and sociological than economic perspectives. The theory argued that companies should demonstrate good social and environmental performance simply because it is morally the right thing to do, irrespective of the business case for or against it (Carroll, 1979; Jones, 1995). Greater focus needs to be made on the measurement of societal outcomes, congruent with stakeholder theory (Klomp \& Clear, 2018). The theoretical perspective is generally understood to mean the reasons for companies to engage in social reporting and what its effects will be on the various stakeholder groups (Ullmann, 1985).

When it comes to the topic of the company-stakeholders relationship, Corporate Social Responsibility (CSR) is the most discussed topic. Ultimately CSR is an advancement of stakeholder theory (Freeman, 1984) with crucial features in constructing building and setting relying on interaction with many different of components (employees, local communities, consumers, environmental activists and concerned residents among numerous others) which is essential to the company's long term accomplishment (Brooks \& Oikonomou, 2018). Besides, stakeholder theory, suggests that companies must protect not only the benefits of shareholders but also those of stakeholders, for instance, employees, suppliers, competitors, and societies (Freeman, 1984). The engagement targeting customers and employees can resolve conflicts between shareholders and primary stakeholders.

A company wishes to contribute limited resources into critical CSR activities which can benefit financial performance, CSR engagement targeting customers and employees is the best choice since customers and employees are primary stakeholders. Previous studies have found that the impact of CSR on financial performance is positive (see: Callan \& Thomas, 2009; Reverte, Gómez-Melero, \& Cegarra-Navarro, 2016; Ting \& Yin, 2018). Filbeck, Gorman, \& Zhao $\underline{(2009)}$ point out that investing in the best corporate citizens results in superior market performance. Gompers, Ishii, \& Metrick (2003) provide ample evidence that companies with strong governance outperform companies with poor governance. Similarly, Humphrey, Lee, \& Shen, (2012) asserts that companies with better social activities have a relative business advantage that allows them to benefit financially from social opportunities and threat

Social Value Creation: Therefore, this study engages the fundamentals of customers' value towards social value creation of engagement projects. For many years, businesses tend to cut cost in a way to increase their profitability. The classic idea of this method is not applicable to business' sustainability (Branco \& Rodrigues, 2006). As businesses make a profit through people, they need to be responsible for giving back to society. A few concepts discussed the overlapping of profit, social, and targets for example corporate social responsibility (Carroll, 2000) and triple bottom line (Elkington, 2001). Thus, businesses today are finding a balanced value creation to achieve both targets (profit and social). Porter \& Kramer (2011) pointed out that the challenges and strategies should aim to create an overall shared value that brings synergy between business and society. The interactions of social value creation with company objectives have great potential in making corporate behaviour more sustainable (Brammer, Jackson, \& Matten, 2012). Consequently, telecommunication companies can synergies their business strategies to have a win-win situation (Ernst \& Young, 2017); both business growth and empower humans for social value creation opportunities. For instance, the service providers provide a platform and at the same time nurturing digital entrepreneurs. Thus, reduce the unemployment rate to achieve a sustainable economy. 
Digitilization: A considerable amount of literature has been published on integrating digitalization development and addressing social issues. Much of the research has focused on how digitalization and big data analytics affect business and social transformation that reshape business models and impact employment amongst knowledge workers (Katz \& Koutroumpis, 2013; Kolk \& Ciulli, 2020; Loebbecke \& Picot, 2015). These efforts help in developing digital ecosystems to provide e-commerce services. Numerous studies have attempted to explain on talents in technology and digitalization, which Fuentes et al.'s (2017) determine the business models of these digital maker-entrepreneurs, meanwhile, Troxler \& Wolf's (2017) reported on how digital maker-entrepreneurs share and exchange goods, services, and knowledge as peers. Previous studies have established women to be exposed to digital entrepreneurial skills to raise their quality of life; for example, Indonesian context (Suwana \& Lily, 2017), Saudi Arabia context (McAdam, Crowley, \& Harrison, 2018).

Besides, to date, the issue of cybersecurity also has been argued on the ground level and a need to have strict policies on this area (Eeten, 2017; Larson, 2017). In a systematic review of 157 papers on digital developments and rural development in advanced countries, Salemink, Strijker, \& Bosworth (2017) found that the lower average levels of education and skills in rural areas hurt adoption and use of digital technologies. Meanwhile, Roberts, Anne, Skerratt, \& Farrington (2017) obtained evident from European to UK country-level, has found that the capacity of digital technology to aid rural development provides solutions to rural service provision. Another issue has been indicated the integration of smart city initiatives and big data has impacted supply chain management (SCM) (Tachizawa, Alvarez-Gil, \& Montes-

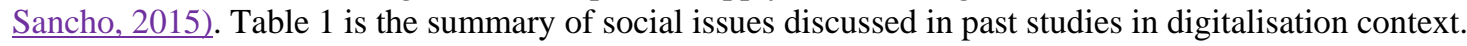

Table 1: Social issues from past studies

\begin{tabular}{|c|c|c|}
\hline & Social issues & Sources \\
\hline [SI1] & $\begin{array}{l}\text { Developing digital ecosystems to provide e- } \\
\text { commerce services }\end{array}$ & $\begin{array}{l}\text { Katz \& Koutroumpis (2013); (Kolk \& Ciulli, } \\
\text { 2020); Loebbecke \& Picot (2015) }\end{array}$ \\
\hline [SI2] & $\begin{array}{l}\text { Discover young talents in technology and } \\
\text { digitalisation for new economy }\end{array}$ & Fuentes et al. (2017); Troxler \& Wolf (2017) \\
\hline [SI3] & Empower women in technology and digitalisation & $\begin{array}{l}\text { McAdam, Crowley, \& Harrison (2018); } \\
\text { Suwana \& Lily (2017); }\end{array}$ \\
\hline [SI4] & $\begin{array}{l}\text { Digital risks and threats including cyberbullying } \\
\text { and online predators }\end{array}$ & Eeten (2017); Larson (2017) \\
\hline [SI5] & $\begin{array}{l}\text { Remove distance as a barrier of technology and } \\
\text { digitalisation }\end{array}$ & $\begin{array}{l}\text { Roberts, Anne, Skerratt, \& Farrington, (2016); } \\
\text { Salemink et al., (2017) }\end{array}$ \\
\hline [SI6] & Manage smart city system (IoT) & $\begin{array}{l}\text { Tachizawa, Alvarez-Gil, \& Montes-Sancho } \\
(2015)\end{array}$ \\
\hline
\end{tabular}

\section{RESEARCH METHOD AND DESIGN}

This study explored the social value creation which applied from corporate social responsibility fundamental concepts. Hence, this study utilized the content analysis method used by many corporate social reporting researchers. The method is a good instrument to measure comparative and trends in reporting (Yusoff, Jamal, \& Darus, 2016). Four leading telecommunication companies that listed in Bursa Malaysia; Axiata, Digi, Maxis and Telekom are chosen as the sample of the study. The study selects the telecommunication industry because digital technology is important in today's world. It is interesting to investigate the capability of the industry beyond digital technologies that they are offering. Content analysis is carried out on annual reports in the year 2016, an important year after National IoT Strategic Map and National e-Commerce Strategic Roadmap and SDG's announcement. The descriptive market information of the sample shows in Table 2 below.

Table 2: Descriptive market information of the sample

\begin{tabular}{lcccc}
\hline & $\begin{array}{c}\text { Market capitalisation as of 31 } \\
\text { Dec 2016 (MYR 000) }\end{array}$ & $\begin{array}{c}\text { Basic EPS } \\
\text { (sen) }\end{array}$ & $\begin{array}{c}\text { Net Dividend } \\
\text { Per Share }\end{array}$ & $\begin{array}{c}\text { Net Tangible Assets/ } \\
\text { (Liabilities) Per Share }\end{array}$ \\
\hline Axiata & $42,345,081$ & 5.70 & 8.00 & 0.05 \\
\hline Digi & $37,553,250$ & 21.00 & 20.90 & 0.01 \\
\hline Maxis & $44,911,668$ & 26.81 & 20.00 & $(0.88)$ \\
\hline Telekom & $22,359,712$ & 20.60 & 21.50 & 1.90 \\
\hline
\end{tabular}

\section{RESULTS}

The six (6) social issue [SI] areas investigated in this study are digital ecosystem [SI1], young talents in technology and digitalisation [SI2], empowerment of women [SI3], digital risks [SI4], rural and urban poor communities [SI5], and smart city system [SI6]. To address SI1, Digi initiated Digi Challenge for Change (DigiCFC7), which aimed to invite local developers to turn their ideas into full-fledged mobile apps. Meanwhile, Axiata provided a few apps, namely KFIT (fitness sharing platform), SUPAHANDS (in-house cloud technology), SLURP! (analytics platform for business efficiency and enhancing customer experience), and TRIPFEZ (aid Muslim-friendly hotels and tours for solution). 
Besides Axiata offered 11street as an e-commerce/m-commerce platform, at the same time providing entrepreneurship skill programme for interested university students to be dynamic retailers to compromise local and global markets in the site. Hence 11street successfully addressed the overlapping of two issues, SI1 and SI2 in the study. It is beneficial to have a developed technology ecosystem (Kolk \& Ciulli, 2020) as it will give an excellent platform and significant impact on the digital system and society in general. For Telekom, the company facilitates the Digital Talent Program under the School of Management, Multimedia Malaysia University (MMU), a university established by TM. Apart from that, to meet SI2, TM recruited schoolchildren for the TM Robotics Programme. Another programme is the TM3Ducation Programme, which is a TM School Adoption programme in collaboration with PINTAR Foundation. This programme aimed to equip talents with knowledge and competencies required.

The empowerment of women has also been highlighted in the social study of digitalisation (Arevalo \& Aravind, 2011). For Digi to address SI3, the company, through Digi Wanita Era Digital (DigiWED), tried to bridge the digital gender gap by equipping women with basic internet and e-commerce skills nationwide. Meanwhile, Telekom handled Smarter Businesses to empower single mothers with knowledge and tools to enhance the income-earning potential of women from Selangor and Klang Valley. The Malaysian Computer Emergency Response Team (MyCERT) reported that the number of online scams in the country is on the rise. A total of 743 fraud cases were received in 1Q2015 (The Star, 2015). Cybercrime is a worrying concern for many digital users (Mohamed, 2012); therefore, to address SI4, Axiata exposed the risks in a Cybersafe Talk for almost 100,000 secondary school students across 964 schools to create awareness of these risks. Meanwhile, Digi organised the Digi CyberSAFE Digital Citizen Camp in collaboration with UNICEF, Generasi Gemilang, RAGE, Protect and Save the Children for educational games and impact sessions.

Distance is one of the barriers of technology that rural communities have been struggling (Salemink et al., 2017). To keep up with digital advancements and increase the communities' participation (Roberts et al., 2017), all of the telecommunication companies have an obtainable high-speed connection through Kampung Tanpa Wayar (KTW) and Pusat Internet 1Malaysia (Pi1M) for underserved (rural and semi-rural) areas. Maxis specifically initiated a value-added programme through Pusat Internet 1Malaysia (Pi1M); the company provides eKelas, technology-enabled teaching and learning that cover academic syllabus to respective communities. Those social value project developments were created to achieve SI5. TM offered IoT-enabled Integrated Operations Centre, thus addressed SI6 which targeted to improve the lives of citizens (Patel, Nordin, \& Al-haiqi, 2014). The residents will enjoy Smart Street Lights Management for better flow of traffic, security surveillance, smart and easy parking securities, energy-efficient water, waste management, and comfortable buildings through the Next-Generation Network (NGN) initiatives.

From the finding, TM was the most participated companies compared to its peers. TM involved in five out of six social issues addressed in this study. Hence, followed by Digi and Axiata with four projects, Maxis was the least participated companies with one social value creation project development. All four companies addressed SI6 which targeted rural and urban poor communities as the development of their vital project, thus creating opportunities for everyone to be digital literate in today's world. Meanwhile, there are many other social issues should be improved in the future.

The understanding of digitalisation and social value creation importance should lead to the formulation of an excellent business strategy for the companies' business growth. In a competitive industry like telecommunication industry, the value-added social services assist in minimising social risks (reduce the unemployment rate, empower women and young adults, reduce cybercrime), hence giving a positive impact on both parties' society and business entity. Table 3 represents the mapping of social issues, SDG, target stakeholders, and project development by the telecommunication companies.

Table 3: The mapping of social issues, SDG, social projects, target stakeholders, and value created that benefitted telecommunication companies and stakeholders

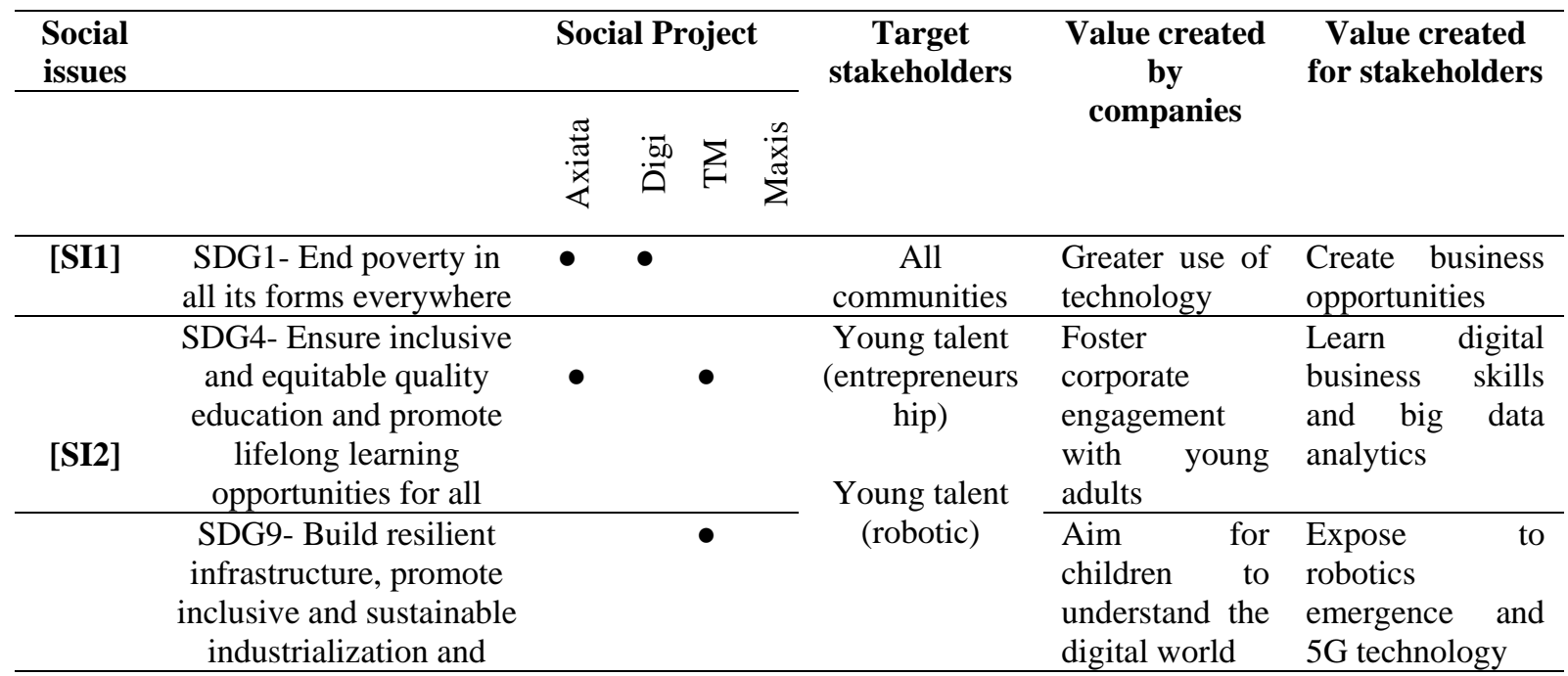




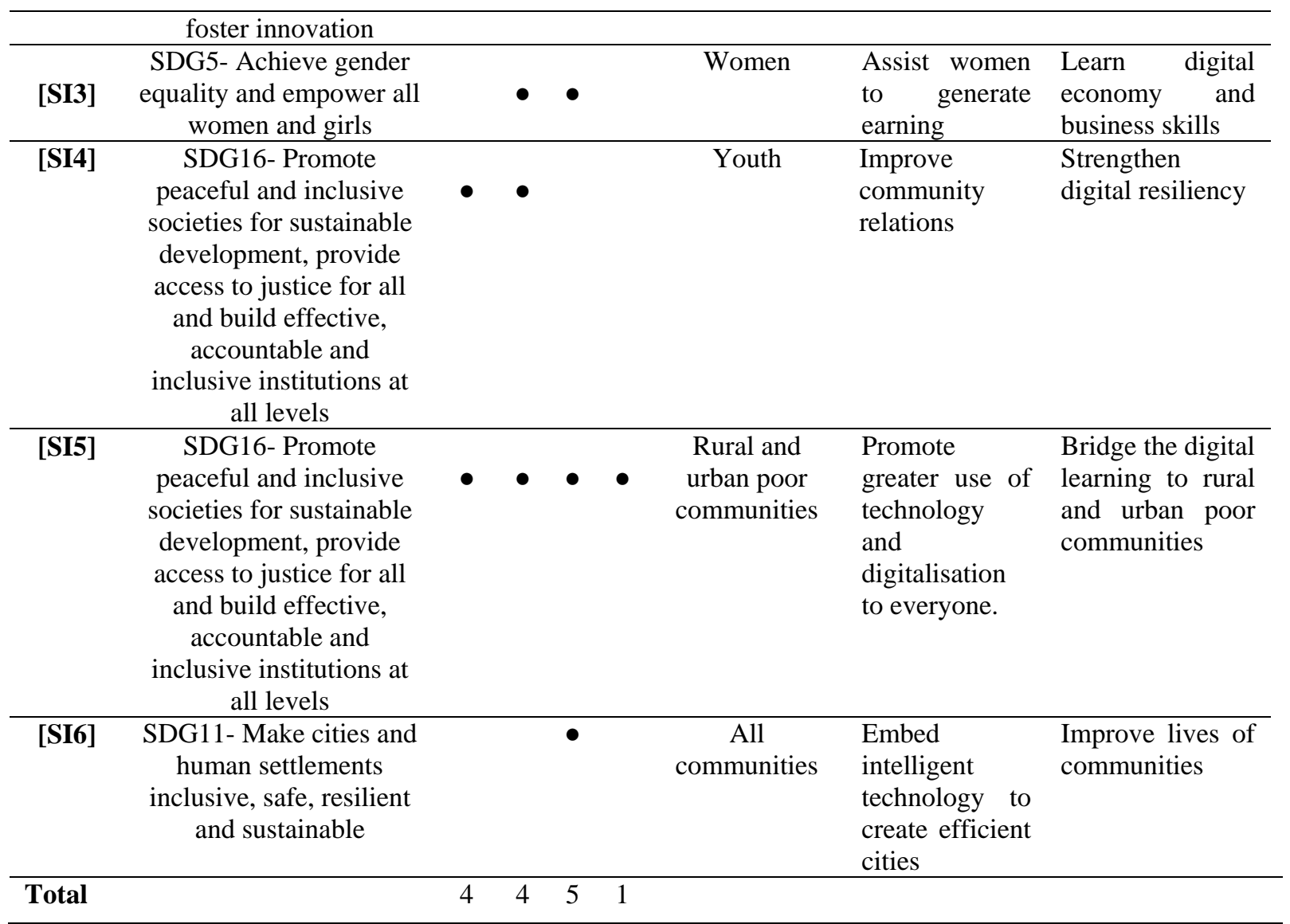

- Social projects that addressed the related social issues.

\section{CONCLUSION}

Most of the telecommunication companies in this study proactively initiate their business strategies that aim to align the social issues to achieve the business, national and international agenda, although there are areas that need to be improved. Therefore, the study would like to refine business strategy in optimising resources and align with national and international agenda. This study has identified six social value creation through stakeholder theory perspective; i) Developing digital ecosystems to provide m-commerce services, ii) Discover young talents in technology and digitalisation for new economy, iii) Empower women in technology and digitalisation, iv) Digital risks and threats including cyberbullying and online predators, v) Remove distance as a barrier of technology and digitalisation and vi) manage smart city system (IoT). The social value creations programmes are expected to meet stakeholder needs (i.e. customers and communities). Among all companies, TM was the champion meanwhile Maxis was the least participated companies in social projects. Similarly, all four companies addressed rural and urban poor communities as their social projects, which consider vital for them.

This study contributed to the current literature in digitalisation social value creation and from Malaysia perspective. Due to practical constraints, this paper cannot provide a comprehensive review of other methods; for example interview. Further work needs to be done to investigate the financial implication of the impactful social projects in line. It is hoped that the social projects will bring impact to societies and function as sustainable business strategy in practice and reporting towards Integrated Reporting (IR) 4.0. From the Malaysian perspective, 'business citizens' are expected in facilitating a sustainable economic growth for the country. Such expectations are in tandem with the mission of Malaysia to become a digital economy nation and achieve a high-income nation status by 2050 (TN50).

\section{ACKNOWLEDGEMENTS}

The authors duly acknowledge the financial support provided by the Minsitry of Higher Education Malaysia under Lestari research grant (600-IRMI/Dana KCM 5/3/LESTARI (144/2017) and FRGS Grant (FRGS/1/2017/SS01/UITM/02/10).

\section{REFERENCES}

1. Accenture \& United Nations Global Compact. (2016). The UN Global Compact-Accenture strategy CEO study. Retrieved from https://www.accenture.com/lv-en/insights/strategy/ungcceostudy

2. Arevalo, J. A., \& Aravind, D. (2011). Corporate social responsibility practices in India: approach, drivers, and barriers. Corporate Governance, 11(4), 399-414. https://doi.org/10.1108/14720701111159244 
3. Berman, S. J. (2012). Digital transformation: opportunities to create new business models. Strategy \& Leadership, 40(2), 16-24. https://doi.org/10.1108/10878571211209314

4. Brammer, S., Jackson, G., \& Matten, D. (2012). Corporate social responsibility and institutional theory: new perspectives on private governance. Socio-Economic Review, 10, 3-28. https://doi.org/10.1093/ser/mwr030

5. Branco, M. C., \& Rodrigues, L. L. (2006). Corporate Social Responsibility and Resource-Based Perspectives. Journal of Business Ethics, 69(2), 111-132. https://doi.org/10.1007/s10551-006-9071-z

6. Brooks, C., \& Oikonomou, I. (2018). Editorial: The effects of environmental, social and governance disclosures and performance on firm value: A review of the literature in accounting and finance. The British Accounting Review, 50(1), 1-15. https://doi.org/10.1016/J.BAR.2017.11.005

7. Brusteinfeb, J. (2012). Start-Ups Seek to Help Users Put a Price on Their Personal Data. Retrieved from https://www.nytimes.com/2012/02/13/technology/start-ups-aim-to-help-users-put-a-price-on-their-personaldata.html

8. Callan, S. J., \& Thomas, J. M. (2009). Corporate financial performance and corporate social performance: an update and reinvestigation. Corporate Social Responsibility and Environmental Management, 16(2), 61-78. https://doi.org/10.1002/csr.182

9. Carroll, A. B. (1979). A Three-Dimensional Conceptual Model of Corporate Performance. Academy of Management Review, 4(4), 497-505. https://doi/10.5465/amr.1979.4498296

10. Carroll, A. B. (2000). A Commentary and an Overview of Key Questions on Corporate Social Performance Measurement. Business \& Society, 39(4), 466-478. https://doi.org/10.1177/000765030003900406

11. Drucker, P. F. (Peter F. (1973). Management : tasks, responsibilities, practices. New York: Harper \& Row.

12. Eeten, M. Van. (2017). Patching security governance : an empirical view of emergent governance mechanisms for cybersecurity. Digital Policy, Regulation and Governance, 19(6), 429-448. https://doi.org/10.1108/DPRG05-2017-0029

13. Elkington, J. (2001). Enter the Triple Bottom Line. The Triple Bottom Line: Does It All Add Up?, 1(1986), 116. https://doi.org/10.1021/n1034968f

14. Ernst \& Young. (2016). Top 10 risks in telecommunications revisited. Retrieved from https://www.ey.com/Publication/vwLUAssets/EY_-_Top_10_risks_in_telecommunications_revisited_2015/ \$FILE/Ey-top-10-risks-revisited.pdf

15. Ernst \& Young. (2017a). Global digital telecom playbook Telcos reinvent themselves in the digital age. Retrieved from https://www.ey.com/Publication/vwLUAssets/ey-global- telecoms-digital-playbook/\$FILE/eyglobal-telecoms-digital-playbook.pdf

16. Ernst \& Young. (2017b). Why Sustainable Development Goals should be in your business plan. Retrieved July 26, 2020, from https://www.ey.com/en_gl/assurance/why-sustainable-development-goals-should-be-in-yourbusiness-plan

17. Filbeck, G., Gorman, R., \& Zhao, X. (2009). The "Best Corporate Citizens": Are They Good for Their Shareholders? Financial Review, 44(2), 239-262. https://doi.org/10.1111/j.1540-6288.2009.00217.x

18. Freeman, R. E. (1984). Strategic management: a stakeholder approach. Boston: Pitman. Retrieved from https://www.worldcat.org/title/strategic-management-a-stakeholder-approach/oclc/9685996

19. Fuentes, C., Bäckström, K., \& Svingstedt, A. (2017). Smartphones and the reconfi guration of retailscapes : Stores , shopping, and digitalization. Journal of Retailing and Consumer Services, 39, 270-278. https://doi.org/10.1016/j.jretconser.2017.08.006

20. Gompers, P., Ishii, J., \& Metrick, A. (2003). Corporate Governance and Equity Prices. The Quarterly Journal of Economics, 118(1), 107-156. https://doi.org/10.1162/00335530360535162

21. Gray, R., Adams, C. A., \& Owen, D. (2014). Accountability, social responsibility, and sustainability: accounting for society and the environment. Pearson United Kingdom

22. Humphrey, J. E., Lee, D. D., \& Shen, Y. (2012). Does it cost to be sustainable? Journal of Corporate Finance, 18(3), 626-639. https://doi.org/10.1016/J.JCORPFIN.2012.03.002

23. Integrated Reporting Committee (IRC) of South Africa. (2011). Framework for integrated reporting and the integrated report: Discussion Paper. Pretoria: Integrated Reporting Committee (IRC) of South Africa. Retrieved from https://integratedreportingsa.org/

24. Jones, T. M. (1995). Instrumental Stakeholder Theory: A Synthesis of Ethics And Economics. Academy of Management Review, 20(2), 404-437. https://doi.org/10.5465/amr.1995.9507312924

25. Katz, R. L., \& Koutroumpis, P. (2013). Measuring digitization: A growth and welfare multiplier. Technovation, 33, 314-319. https://doi.org/10.1016/j.technovation.2013.06.004

26. ATKearney (2015). Lifting the Barriers to E-Commerce in ASEAN. Retrieved from https://retailnewstrends.files.wordpress.com/2015/07/asia-at-kearney-lifting-the-barriers-to-e-commerce-inasean.pdf

27. Keegan, S. (2012). Digital technologies are re-shaping our brains: What are the implications for society and the research industry? Qualitative Market Research: An International Journal, 15(3), 328-346. https://doi.org/10.1108/13522751211232012

28. Klomp, S., \& Clear, A. (2018). Senior Management Perceptions of CSR Impact: Long-term Investment for Social Good or Necessary Cost? (pp. 177-191). Springer, Cham. https://doi.org/10.1007/978-3-319-71449- 
3_11

29. Kolk, A. (2010). Trajectories of sustainability reporting by MNCs. Journal of World Business, 45(4), 367-374. https://doi.org/10.1016/J.JWB.2009.08.001

30. Kolk, A., \& Ciulli, F. (2020). The potential of sustainability-oriented digital platform multinationals: A comment on the transitions research agenda. Environmental Innovation and Societal Transitions, 34(January), 355-358. https://doi.org/10.1016/j.eist.2019.12.008

31. KPMG. (2011). KPMG International Survey of Corporate Responsibility Reporting 2011. Retrieved from http://pure.au.dk/portal/files/45289845/bilag_5_KPMG_unders_gelse.pdf

32. Larson, J. F. (2017). Network-centric digital development in Korea: Origins, growth and prospects. Telecommunications Policy, 41(10), 916-930. https://doi.org/10.1016/j.telpol.2017.03.007

33. Lee, K.-H., \& Kim, C. H. (2014). Corporate Social Responsibility (CSR) Practice and Implementation Within the Institutional Context: The Case of the Republic of Korea (pp. 65-82). Springer, Cham. https://doi.org/10.1007/978-3-319-01532-3_4

34. Loebbecke, C., \& Picot, A. (2015). Reflections on societal and business model transformation arising from digitization and big data analytics : A research agenda. Journal of Strategic Information Systems, 24(3), 149157. https://doi.org/10.1016/j.jsis.2015.08.002

35. McAdam, M., Crowley, C., \& Harrison, R. T. (2018). "To boldly go where no [man] has gone before" Institutional voids and the development of women's digital entrepreneurship. Technological Forecasting and Social Change. https://doi.org/10.1016/J.TECHFORE.2018.07.051

36. Mohamed, D. (2012). Combating the threats of cybercrimes in Malaysia: The efforts, the cyberlaws and the traditional laws. Computer Law \& Security Review, 29(1), 66-76. https://doi.org/10.1016/j.clsr.2012.11.005

37. Mottain, M. (2017). Malaysia in the new economy. The Star. Retrieved from https://www.thestar.com.my/business/business-news/2017/02/04/malaysia-in-the-new-economy/

38. Negroponte, N. (1995). Being digital. New York, NY: Vintage Books.

39. Paetzold, F. (2011). Sustainable Investing in Asia: Uncovering Opportunities and Risks. In Responsible Management in Asia (pp. 256-276). London: Palgrave Macmillan UK. https://doi.org/10.1057/9780230306806_16

40. Passig, K., \& Scholz, A. (2015). Schlamm und Brei und Bits. Warum es die Digitalisierung nicht gibt. Merkur, 69(798), 75-81. Retrieved from https://volltext.merkur-zeitschrift.de/article/99.120210/mr-69-11-75

41. Patel, A., Nordin, R., \& Al-haiqi, A. (2014). Computer Standards \& Interfaces Beyond ubiquitous computing : The Malaysian HoneyBee project for Innovative Digital Economy. Computer Standards \& Interfaces, 36(5), 844-854. https://doi.org/10.1016/j.csi.2014.01.003

42. Polman, P. (2014). Business, society, and the future of capitalism | McKinsey. Retrieved May 26, 2019, from https://www.mckinsey.com/business-functions/sustainability/our-insights/business-society-and-the-future-ofcapitalism

43. Porter, M. E., \& Kramer, M. R. (2011). The big idea: creating shared value. Harvard Business Review, 41(1), 12-13. https://doi.org/10.2469/dig.v41.n1.28

44. Reverte, C., Gómez-Melero, E., \& Cegarra-Navarro, J. G. (2016). The influence of corporate social responsibility practices on organizational performance: evidence from Eco-Responsible Spanish firms. Journal of Cleaner Production, 112, 2870-2884. https://doi.org/10.1016/J.JCLEPRO.2015.09.128

45. Roberts, E., Anne, B., Skerratt, S., \& Farrington, J. (2017). A review of the rural-digital policy agenda from a community resilience perspective. Journal of Rural Studies, 54, 372-385. https://doi.org/10.1016/j.jrurstud.2016.03.001

46. Salemink, K., Strijker, D., \& Bosworth, G. (2017). Rural development in the digital age : A systematic literature review on unequal ICT availability, adoption, and use in rural areas. Journal of Rural Studies, 54, 360-371. https://doi.org/10.1016/j.jrurstud.2015.09.001

47. Suwana, F., \& Lily. (2017). Empowering Indonesian women through building digital media literacy. Kasetsart Journal of Social Sciences, 38(3), 212-217. https://doi.org/10.1016/j.kjss.2016.10.004

48. Tachizawa, E. M., Alvarez-Gil, M. J., \& Montes-Sancho, M. J. (2015). How "smart cities" will change supply chain. Supply Chain Management: An International Journal, 20(3), 237-248. https://doi.org/10.1108/SCM-032014-0108

49. The Star. (2015, December). E-commerce set for growth. Retrieved from https://www.thestar.com.my/metro/smebiz/news/2015/12/28/ecommerce-set-for-growth/

50. Troxler, P., \& Wolf, P. (2017). Digital maker-entrepreneurs in open design: What activities make up their business model? Business Horizons, 60(6). https://doi.org/10.1016/j.bushor.2017.07.006

51. Ullmann, A. A. (1985). Data in Search of a Theory: A Critical Examination of the Relationships Among Social Performance, Social Disclosure, and Economic Performance of U.S. Firms. Academy of Management Review, 10(3), 540-557. https://doi.org/10.5465/amr.1985.4278989

52. World Economic Forum. (2017). The 10 countries best prepared for the new digital economy. Retrieved from https://www.weforum.org/agenda/2016/07/countries-best-prepared-for-the-new-digital-economy/

53. Yigitcanlar, T., \& Sarimin, M. (2015). Multimedia Super Corridor, Malaysia: knowledge-based urban development lessons from an emerging economy. VINE, 45(1), 126-147. https://doi/10.1108/VINE-06-2014- 
Humanities \& Social Sciences Reviews elSSN: 2395-6518, Vol 8, No 2, 2020, pp 948-956 https://doi.org/10.18510/hssr.2020.82105

0041/full/html

54. Yusoff, H., Jamal, A. D., \& Darus, F. (2016). Corporate Governance and Corporate Social Responsibility Disclosures: An Emphasis on the CSR Key Dimensions. Journal of Accounting and Auditing: Research \& Practice, 2016, 1-14. https://doi.org/10.5171/2016.476550 